\title{
Grazing rates and feeding preferences of the mysid shrimp Gastrosaccus brevifissura in a temporarily open estuary in South Africa
}

\author{
Israel Kibirige $^{1}$, Renzo Perissinotto ${ }^{1, *}$, Christian Nozais $^{2}$ \\ ${ }^{1}$ School of Life and Environmental Sciences, George Campbell Building, University of Natal, Durban 4041, South Africa \\ ${ }^{2}$ Institut des Sciences de la Mer de Rimouski (ISMER), Université du Québec à Rimouski, 310 Allée des Ursulines, \\ Rimouski G5L 3A1, Québec, Canada
}

\begin{abstract}
Gastrosaccus brevifissura is a key crustacean species in most South African estuaries. The biomass, distribution, grazing rates and feeding preferences of this species were investigated in the Mpenjati Estuary, on the east coast of South Africa. The species exhibits a very marked diurnal migration behaviour, with biomass varying within the range 0.005 to $0.26 \mathrm{~g} \mathrm{~m}^{-3}$ dry wt (DW) during the daytime and 0.002 to $1.53 \mathrm{~g} \mathrm{~m}^{-3} \mathrm{DW}$ during the night. The estimated total population grazing impact of the mysid ranged between 22 and $32 \%$ of the available phytoplankton in summer and winter, respectively. This suggests that $G$. brevifissura may not meet all its metabolic demands by consuming phytoplankton alone. Other possible food sources available in the estuary include plant detritus (DTR), microheterotrophs and benthic microalgae (BMA). In particular, the vertical migration behaviour of $G$. brevifissura allows close spatial association with the benthic microalgae during most of the day. Indeed, feeding experiments suggest that G. brevifissura is able to feed efficiently on settled as well as on resuspended benthic microalgae. This is supported by results from stable isotope analysis $\left(\delta^{13} \mathrm{C}\right.$ and $\left.\delta^{15} \mathrm{~N}\right)$, which show that benthic microalgae contribute 68 and $24 \%$ to the total diet of G. brevifissura in winter and summer, respectively. This also suggests that other food sources are needed by this species to meet all its energetic demands. Carbon rations obtained from in situ grazing methods are 35 to $44 \%$ (winter) and 1.6 to $3.9 \%$ (summer). When these values are compared to the previously estimated basal metabolic requirements for the mysid, it follows that G. brevifissura is able to meet all its energetic requirements from a pure autotrophic diet only during the winter. On the other hand, during summer, these values are barely enough to meet the basal metabolic rate of this species.
\end{abstract}

KEY WORDS: Grazing rates · Mysidacea - Phytoplankton - Benthic microalgae - Metabolic requirements · Daily ration

\section{INTRODUCTION}

Over $73 \%$ of South Africa's estuaries are of a temporarily open nature, as defined by Whitfield (1992); i.e. these estuaries are open to the sea during the summer rainy season but are cut off (closed) during the dry winter, as a sandbar develops at the mouth when the inflow of freshwater decreases. The physico-chemical parameters of the 2 phases differ considerably (Whitfield 1992, Perissinotto et al. 2000). Zooplankton bio- mass and abundance are generally high, dominated by copepods and mysids, and exhibit major variations in response to physico-chemical changes that occur between the open and closed phases (Perissinotto et al. 2000, Kibirige 2002). On the other hand, the phytoplankton standing stock of temporarily open estuaries is relatively low during both phases compared to that in their permanently open counterparts (Perissinotto et al. 2000, Nozais et al. 2001). This suggests that in temporarily open estuaries the available phytoplank- 
ton biomass may not always be enough to meet all the energetic demands of the grazers. Therefore, other food sources may be important in achieving an energy balance for the grazers, particularly during periods of phytoplankton scarcity (Perissinotto et al. 2000).

Estuarine mysids are known to feed on phytoplankton (Siegfried \& Kopache 1980, Webb et al. 1987), sediment and epiphytic algae (Fleeger et al. 1999), microzooplankton (Jerling \& Wooldridge 1995a) and mesozooplankton (Siegfried \& Kopache 1980, Wooldridge \& Bailey 1982, Wooldridge \& Webb 1988, Jerling \& Wooldridge 1995b). The mysids are in turn consumed (mainly) by a variety of fish species (Siegfried \& Kopache 1980, Talbot \& Baird 1985). The mysid Gastrosaccus brevifissura (Tattersall 1952) is one of the dominant crustacean species in both permanently and temporarily open estuaries of southern Africa (Tattersall 1952, Brown \& Talbot 1972, Wooldridge 1976, 1977, Wooldridge \& McLachlan 1987, Webb et al. 1997). It is a suprabenthic organism that burrows in the sediment during the day and displays pelagic behaviour during the night (Brown \& Talbot 1972).

There is a lack of information on the grazing rates and feeding preferences of mysid shrimps in temporarily open estuaries. In view of the high grazing rates of Gastrosaccus brevifissura, its high biomass compared to other dominant zooplankton species (Kibirige 2002) and its benthic-pelagic behaviour, it is important to establish whether the bulk of its energy intake comes from material resuspended in the water column or from material within the sediment. Therefore, this study investigated the grazing dynamics of the mysid shrimp G. brevifissura in the Mpenjati Estuary in relation to the availability of phytoplankton and benthic microalgae (BMA). It also addressed the question of whether this autotrophic material is sufficient to meet all the energy requirements of the mysid.

\section{MATERIALS AND METHODS}

Samples of Gastrosaccus brevifissura for abundance and biomass analysis were collected from the lower reaches of the Mpenjati Estuary (Fig. 1) every second month between August 1998 and September 1999, both at night and during the day, using a UNESCO WP-2 net (Tranter \& Fraser 1968) of $90 \mu \mathrm{m}$ mesh size fitted with a General Oceanics flowmeter. Horizontal tows were made from a flat-bottomed boat, with the upper part of the net kept 5 to $10 \mathrm{~cm}$ below the surface. In the laboratory, subsamples for enumeration were drawn off the samples, which had been suspended in 1 to $10 \mathrm{l}$ solutions, depending on the zooplankton concentration. A $25 \mathrm{~cm}$-long glass tube, $10 \mathrm{~mm}$ in diameter, was used to withdraw duplicate subsamples

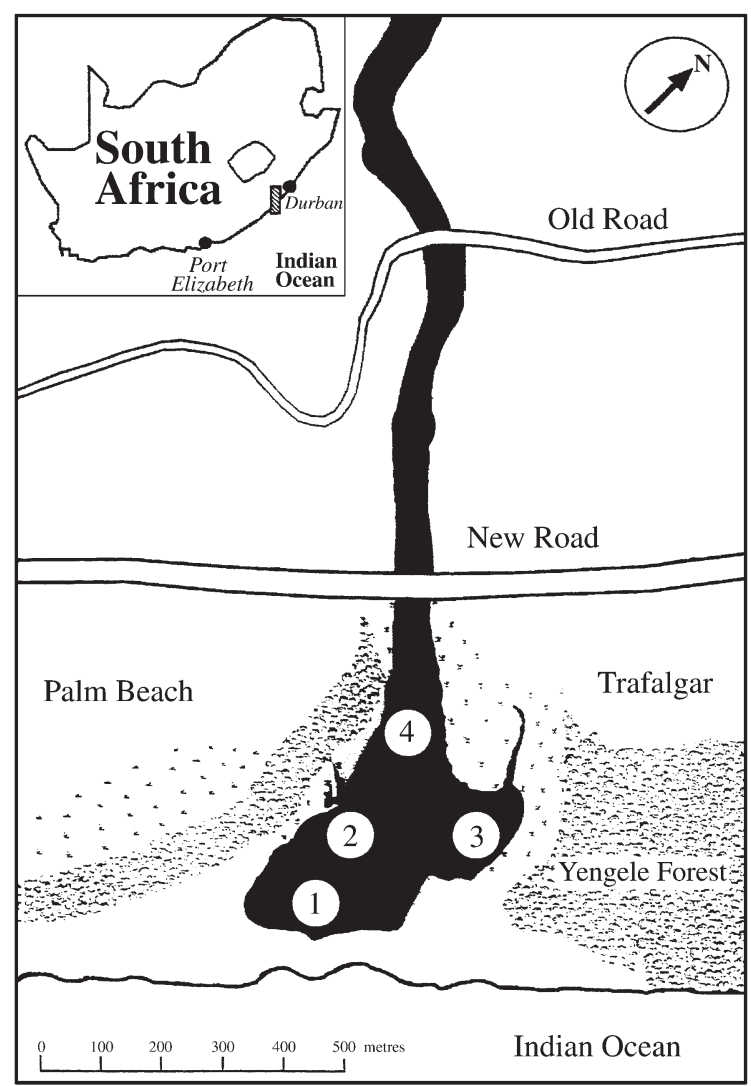

Fig. 1. Map of Mpenjati Estuary, South Africa, showing Sations (1 to 4 ) where mysids were collected during the study. Latitude and longitude at estuary mouth $=30^{\circ} 58^{\prime} \mathrm{S}, 30^{\circ} 17^{\prime} \mathrm{E}$

from the suspension: the tube was inserted to the bottom of the suspension, and settlement was prevented by continuous stirring (Perissinotto \& Wooldridge 1989, Jerling \& Wooldridge 1995b). The coefficient of variation between subsamples was consistently less than $10 \%$. Species abundance was expressed as numbers $\mathrm{m}^{-3}$, while biomass was estimated gravimetrically as dry weight by drying individual samples at $60^{\circ} \mathrm{C}$ for $24 \mathrm{~h}$ in a laboratory oven (Pakhomov \& Perissinotto 1996).

The grazing rates of the mysid were estimated using an in situ approach in August 1999 and in February 2000, in the lower reaches of the estuary where the species normally occurred during the study period. For this purpose, the gut pigment technique of Mackas \& Bohrer (1976) was used in combination with estimates of gut-evacuation and pigment-destruction rates (Perissinotto 1992, Kibirige \& Perissinotto 2003). Mysids were collected from the sediment with a D-net during the day, and from the water column with a WP-2 net during the night. The D-net of $500 \mu \mathrm{m}$ mesh was operated by hand to scrape the upper 0.5 to $1 \mathrm{~cm}$ layer of sand for a distance of about 5 to $10 \mathrm{~m}$ in the lower reaches of the estu- 
ary. All specimens used in the laboratory feeding experiments were collected with the D-net.

For the measurement of gut-pigment contents, 5 Gastrosaccus brevifissura individuals were used in each of the 5 replicate test tubes. Pigments were coldextracted $\left(2^{\circ} \mathrm{C}\right)$ for $24 \mathrm{~h}$ in the test tubes after addition of 7 to $10 \mathrm{ml}$ of $90 \%$ acetone. Pigment concentrations were measured fluorometrically (Turner 10-AU) using a narrow-band system with no acidification (Welschmeyer 1994, Nozais et al. 2001). Gut-evacuation rates were monitored by checking the decline in gut content at intervals of $10 \mathrm{~min}$ for the first $40 \mathrm{~min}$ and at intervals of 20 min thereafter. For each time interval measurement, 5 (August 1999) or 4 (February 2000) replicates were used. Again, 5 individuals per replicate measurement were pooled in a test tube. In these experiments, the mysids were incubated in $10 \mathrm{l}$ volumes of filtered estuarine water (FEW) at an ambient temperature of $20^{\circ} \mathrm{C}$ in August 1999 or $25^{\circ} \mathrm{C}$ in February 2000.

Estimates of gut-pigment destruction in Gastrosaccus brevifissura were obtained both during winter 1999, summer 2000 and again in winter 2001. In all cases, the loss of pigments to non-fluorescent endproducts, by either absorption or destruction, was estimated during $24 \mathrm{~h}$ incubations, as described in detail elsewhere (Perissinotto 1992). The purpose of the experiments in 2001 was mainly to determine whether there are differences in the rate of pigment destruction when mysids are offered different microalgal diets. One incubation was carried out using a mixture of naturally occurring diatoms and a second used an unidentified species of Euglena that was present in abundance in the sediments of the estuary during the 2001 sampling.

In vitro grazing experiments were carried out to test the hypothesis that Gastrosaccus brevifissura is not only able to feed on microalgae suspended in the water column, but also on microalgae settled in the sediment or at least at the sediment-water interface. Benthic microalgae for these experiments were collected using a glass tube drawn across the upper surface of the sediment (to ca. $1 \mathrm{~cm}$ depth), where the densest concentrations of microalgae are normally found (Round 1981, De Jonge \& Colijn 1994, Cariou-Le Gall \& Blanchard 1995). Within $1 \mathrm{~h}$ of collection, the mixture was transported to the laboratory, where BMA were separated on the basis of their vertical migration properties (Couch 1989, Riera \& Richard 1996). Samples were placed in petri dishes (14 $\mathrm{cm}$ inner diameter) to a maximum sediment depth of $1 \mathrm{~cm}$. After 4 to $6 \mathrm{~h}$, the supernatant was removed with a pipette, a $90 \mu \mathrm{m}$ mesh was placed on the sediment surface and covered with a 4 to $5 \mathrm{~mm}$ layer of combusted silica gel powder (ca. 90 to $200 \mu \mathrm{m}$ diameter). This was then covered with a sec- ond $90 \mu \mathrm{m}$ mesh. The silica gel was kept wet with filtered estuarine water. The petri dishes were held under fluorescent light for 2 to $6 \mathrm{~h}$ to allow the motile microalgae to migrate to the top mesh through the first mesh and the silica gel. Periodically (i.e. 1 to $2 \mathrm{~h}$ intervals), the top mesh was removed and rinsed with FEW to harvest the microalgae.

Feeding preferences and in vitro grazing rates on BMA were investigated using 3 treatments: (1) resuspended microalgae (RM); (2) settled microalgae (SM); and (3) permanent light (PL) with an intensity similar to a shaded natural light of $\sim 230 \mu \mathrm{mol} \mathrm{m}^{-2} \mathrm{~s}^{-1}$ output (Lobban et al. 1985, Mallin \& Paerl 1994). Each experimental treatment consisted of 4 replicates of $250 \mathrm{ml}$ feeding bottles, and 1 final control bottle (without mysids). Each bottle contained 5 Gastrosaccus brevifissura adults of approximately the same size (10 to $12 \mathrm{~mm}$ total length). In the RM treatment, there was no sediment and the bottles were periodically shaken to avoid settling of the microalgae. This treatment allowed continuous swimming of the mysids throughout the feeding experiment and kept the BMA resuspended in the water column. In the SM treatment, the feeding bottles had a layer of sand and microalgae were allowed to settle at the bottom. Here, mysids were able to move up the water column as well as burrow into the sediment in accordance with their natural diel cycle. Both treatments were kept outside and were thus exposed to the natural light cycle (approx. $11 \mathrm{~h}$ light, $13 \mathrm{~h}$ dark). The PL treatment, on the other hand, used sediment with settled microalgae, but a cool fluorescent light was used to illuminate the feeding bottles throughout the feeding period of $24 \mathrm{~h}$. This procedure forced the mysids to burrow permanently into the sediment or at least to remain at the sediment-water interface. In all 3 treatments, BMA concentrations were $210 \mathrm{mg}$ chlorophyll a (chl a) $\mathrm{m}^{-2}$, corresponding to average values in the Mpenjati Estuary during the period of investigation (Perissinotto et al. 2002).

Prior to the feeding experiments, aliquots of $200 \mathrm{ml}$ of microalgal suspension were removed from a $10 \mathrm{l}$ stock solution while stirring (to ensure that no resettlement of the BMA occurred). Each aliquot was then divided into two $100 \mathrm{ml}$ samples, one was added to the respective $250 \mathrm{ml}$ feeding/control bottle, the other was filtered onto a GF/F filter. The filter was then placed in a $100 \mathrm{ml}$ polyethylene bottle containing $30 \mathrm{ml}$ of acetone to measure fluorometrically the initial concentration of chl a. After $24 \mathrm{~h}$ incubation, all mysids were removed from the feeding bottles and the entire volume of water from each bottle was filtered through a GF/F filter. The filter was then returned to the grazing bottle and pigments from both sand and filter (settled microalgae and permanent light treatments) or filter only (suspended microalgae treatment) were extracted 
with $30 \mathrm{ml}$ of $90 \%$ acetone. Control samples were processed in exactly the same way.

All samples were kept in darkness at $2^{\circ} \mathrm{C}$ for $24 \mathrm{~h}$, after which chl a was measured fluorometrically (Welschmeyer 1994). The difference between initial and final pigment concentrations (chl a + phaeopigments) was taken as the amount of pigments ingested by the mysids, after correction for pigment lost in the control bottle associated with each experiment (Frost 1972).

Filtration rates were also calculated and used to indicate the volume of ambient medium from which microalgae cells were completely removed by the grazers (Frost 1972, Peters 1984). Filtration rates were estimated using the equations of Marin et al. (1986):

$$
F=V G_{0} / N
$$

where $F$ is the volume swept clear per unit time ( $\mathrm{ml}$ ind.$^{-1} \mathrm{~h}^{-1}$ ), $V$ is the volume of the feeding/grazing bottle $(\mathrm{ml}), G_{\mathrm{o}}$ is the grazing coefficient at the initial chl a concentration and $N$ is the number of grazers in each bottle. Finally, the ingestion rate, I (ng pigment ind. ${ }^{-1} \mathrm{~h}^{-1}$ ) was calculated using the standard relationship (Frost 1972, Marin et al. 1986, Ribes et al. 1998):

$$
I=F C
$$

where $C$ is the BMA concentration (ng pigment $\mathrm{m}^{-2}$ ) consumed in the grazing bottle. Normally, filtration rates decrease as the food concentration increases beyond a critical concentration (Rigler 1971, Frost 1972). In order to determine whether the food concentration was limiting ingestion rates during the experiments, the equations of Huntley \& Boyd (1984) were used. The estimated critical concentration ranged

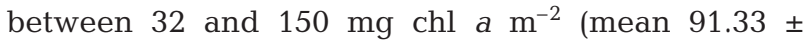
59.0 SD mg chl a m $\mathrm{m}^{-2}$ ). This value was much lower than the ambient concentration of $210 \mathrm{mg}$ chl a m $\mathrm{m}^{-2}$ used in the feeding experiments, suggesting that the zooplankton used in this study were not food-limited. Differences between treatments were analysed with a 1-way ANOVA, and where significant differences were detected a Tukey HSD post hoc test was applied to determine the source of variation.

For the stable isotope analysis, BMA, particulate organic matter (POM) and detritus (DTR) were obtained from the estuary along with samples of the mysid. The protocol for the extraction of BMA used in the isotopic analysis is similar to that described above. In this case, however, once extracted, the BMA samples were freeze-dried before analysis. Approximately $2 \mathrm{mg}$ samples were then weighed and packed in tin capsules for analysis with a mass spectrometer. The fringing plants, mainly vascular plants, on the banks of the estuary were assumed to constitute the bulk of the DTR found in the water column (Jerling \& Wooldridge 1995c). Therefore, small samples of the dominant plant species were collected and freeze-dried, homogenized, weighed, and packed in tin capsules for analysis with a mass spectrometer. Stable isotope analyses $\left(\delta^{13} \mathrm{C}\right.$ and $\delta^{15} \mathrm{~N}$ ) for the food sources and Gastrosaccus brevifissura were carried out with a Carlo Erba NAISOO II elemental analyser interfaced with a Finnigan Mat 252 mass spectrometer via a Conflo II open-split device at the Archaeometry Unit of the University of Cape Town.

Water samples for POM measurement were collected from the Mpenjati Estuary with a weighted bottle-sampler, 5 to $10 \mathrm{~cm}$ below the surface, and sieved through a $200 \mu \mathrm{m}$ mesh to remove large zooplankton. Samples were then filtered through precombusted glass fibre filters (Whatman GF/F) within $1 \mathrm{~h}$ of collection. This was followed by acidification with 1.0 $\mathrm{M} \mathrm{HCl}$ to remove the carbonates. Finally, samples were freeze-dried and kept frozen $\left(-40^{\circ} \mathrm{C}\right)$ until analysis with a mass spectrometer, as for the other samples.

Gastrosaccus brevifissura samples for stable isotope analysis were collected during winter (June 1999) and summer (February 2000) from the lower reaches of the Mpenjati Estuary using a WP-2 $90 \mu \mathrm{m}$ net. For this purpose, samples were immediately frozen on dry ice and brought back to the laboratory. Within $24 \mathrm{~h}$ of collection, the gut content was removed, and the mysids were rinsed with deionized water to avoid contamination of the gut contents (Stoner \& Zimmerman 1988). Lipids were also removed by soaking the samples for 5 to $6 \mathrm{~h}$ in a defatting solution containing chloroform, methanol, and distilled water in the proportions of 2:1:0.8 (Bligh \& Dyer 1959). Samples were then soaked in $1.0 \mathrm{M} \mathrm{HCI}$ for 2 to $4 \mathrm{~h}$ to remove carbonates that could interfere with the carbon isotope values (Hedges \& Parker 1976, Schwinghamer et al. 1983, Tan et al. 1991). Samples were finally washed free of excess acid, freeze-dried, weighed and packed in tin capsules for analysis with the mass spectrometer, as for the BMA.

Trophic and environmental parameters measured in the estuary during the study included phytoplankton and microphytobenthic biomass, temperature and salinity. Water column and microphytobenthic chl a samples were measured fluorometrically with a Turner 10-AU, as described in detail elsewhere (see Nozais et al. 2001, Perissinotto et al. 2002). Temperature and salinity were recorded during each survey with a YSI 6920 water logger.

\section{RESULTS}

Water temperature in the estuary ranged between 19 and $21^{\circ} \mathrm{C}$ during winter and between 21 and $28^{\circ} \mathrm{C}$ during summer. Salinity showed a marked vertical gradient, with values ranging from 13 (surface) to 21\%o 


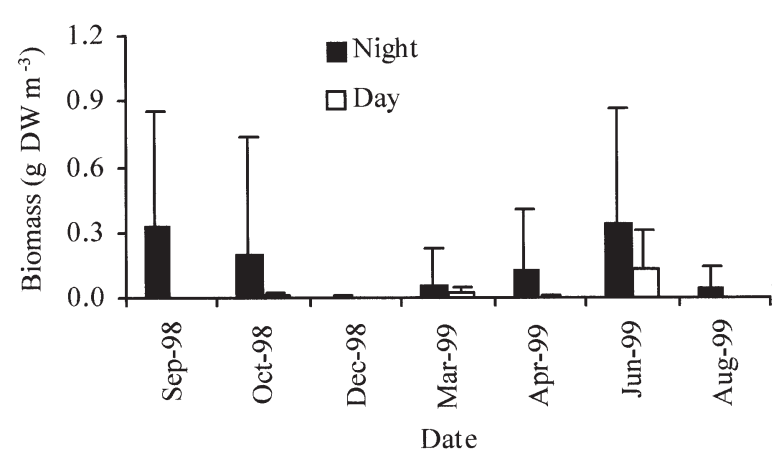

Fig. 2. Gastrosaccus brevifissura. Biomass (dry weight, mean + SD) during daytime and night-time in closed (September and October 1998) and open (December to April 1999) phases of the Mpenjati Estuary

(bottom) in winter and from 24 (surface) to $32 \%$ (bottom) in summer. During the winter closed phase (August 1999), phytoplankton chl a concentration varied between 9.0 and $19.6 \mathrm{mg} \mathrm{m}^{-3}$ (mean $13 \pm 4.6 \mathrm{SD} \mathrm{mg}$ $\mathrm{m}^{-3}$ ) at the surface, and between 16.2 and $23.2 \mathrm{mg} \mathrm{m}^{-3}$ (mean 18.6 $\pm 3.0 \mathrm{SD} \mathrm{mg} \mathrm{m}^{-3}$ ) at the bottom. In summer (February 2000), phytoplankton chl a concentration ranged from 1.01 to $2.3 \mathrm{mg} \mathrm{m}^{-3}$ (mean $1.55 \pm 0.60 \mathrm{SD}$ $\mathrm{mg} \mathrm{m}^{-3}$ ) and from 1.04 to 3.48 (mean $2.04 \pm 1.13 \mathrm{SD} \mathrm{mg}$ $\left.\mathrm{m}^{-3}\right)$, at the surface and bottom, respectively. Microphytobenthic chl a concentrations ranged from 21.4 to $350 \mathrm{mg}$ chl a m${ }^{-2}$ (mean $217 \pm 91 \mathrm{SD} \mathrm{mg} \mathrm{m}{ }^{-3}$ ) during August 1999 and from 5.0 to $293 \mathrm{mg} \mathrm{chl} \mathrm{a} \mathrm{m}{ }^{-2}$ (mean $118 \pm 80.8 \mathrm{SD} \mathrm{mg} \mathrm{m}^{-3}$ ) in February 2000 .

The abundance and biomass of Gastrosaccus brevifissura in the water column of the Mpenjati Estuary varied greatly between daytime and night-time. Highest abundances were observed at night-time, with values ranging from 226 ind. $\mathrm{m}^{-3}$ in March 1999 to 1075 ind. $\mathrm{m}^{-3}$ in September 1998. Conversely, very few individuals occurred in the water column during the day, with values ranging from 4 ind. $\mathrm{m}^{-3}$ in April 1999 to 6 ind. $\mathrm{m}^{-3}$ in March 1999. Similarly, the highest biomass levels of $1.53 \mathrm{~g} \mathrm{DW} \mathrm{m}^{-3}$ (mean $0.33 \pm 0.53 \mathrm{SD} \mathrm{g}$

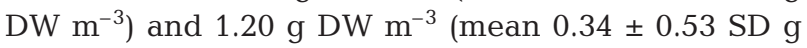
DW m ${ }^{-3}$ ) were observed at night in September 1998 and June 1999, respectively (Fig. 2).

There were significant day/night differences in the gut pigment contents of Gastrosaccus brevifissura (Student's $t=3.64, \mathrm{p}<0.05$; August 1999; $t=4.15, \mathrm{p}<$ 0.05 ; February $2000 ; t=6.21, \mathrm{p}<0.05$; July 2001), with night values being on average 2 to 3 times higher than the day values (Fig. 3). During August 1999, the maximum of $5.37 \mathrm{ng}$ pigment ind. ${ }^{-1}$ (mean $3.4 \pm 1.3 \mathrm{SD}$ ng pigment ind..$^{-1}$ ) was recorded during the night, while the minimum of $0.27 \mathrm{ng}$ pigment ind. ${ }^{-1}$ (mean $1.2 \pm$ $0.7 \mathrm{SD}$ ng pigment ind. ${ }^{-1}$ ) was measured during the day (Fig. 3a). In February 2000, G. brevifissura gut pigment contents ranged from 0.56 to $3.36 \mathrm{ng}$ pigment
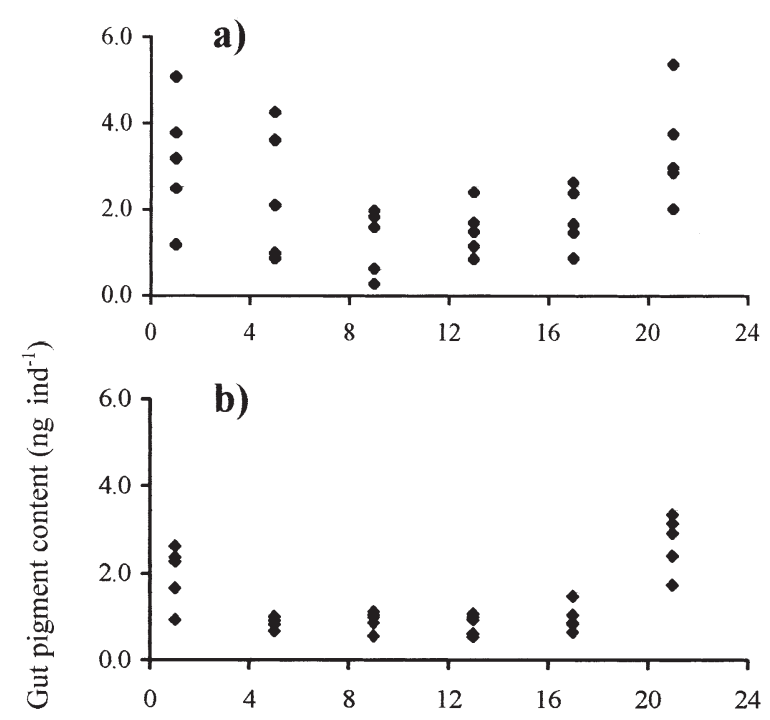

c)

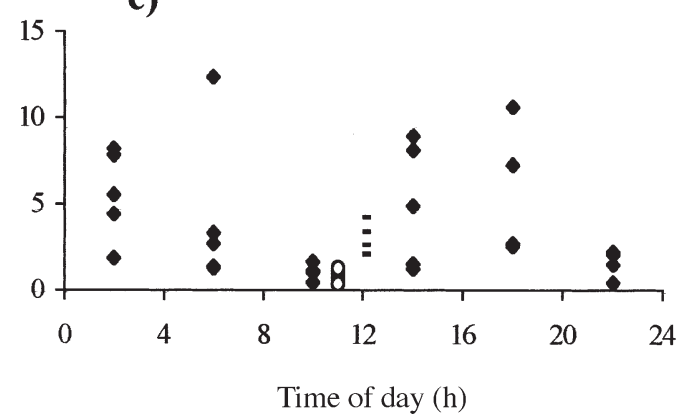

Fig. 3. Gastrosaccus brevifissura. Diel gut-pigment content during (a) 24 and 25 August 1999, (b) 28 February 2000, (c) 22 and 23 June $(\bullet), 4$ July $(0)$ and 18 July $(\boldsymbol{\square}) 2001$ in the Mpenjati Estuary

ind. ${ }^{-1}$ (mean $1.37 \pm 0.83 \mathrm{SD}$ ng pigment ind..$^{-1}$ ), with the highest values again observed during the night (Fig. 3b). During July 2001, gut-pigment contents ranged from 0.42 to $12.35 \mathrm{ng}$ pigment ind. ${ }^{-1}$ (mean $3.81 \pm 3.32 \mathrm{SD}$ ng pigment ind. ${ }^{-1}$ ) during the night and from 0.47 to $10.58 \mathrm{ng}$ pigment ind..$^{-1}$ (mean $3.67 \pm$ 3.45 SD ng pigment ind..$^{-1}$ ) during the day (Fig. 3c).

The gut-evacuation rates in August 1999 and in February 2000 were 0.62 and $0.68 \mathrm{~h}^{-1}$, respectively (Fig. 4). Unfortunately, it was not possible to measure gut-evacuation rates again in July 2001 because of the low density of mysids during this period. The extent of gut-pigment destruction was highly consistent on all 3 occasions, ranging from 99.0 to $99.7 \%$ (mean $99.6 \pm$ $0.39 \mathrm{SD} \%$ ) of the total pigment ingested. There were also no significant differences in gut-pigment destruction between mysids fed a diatom mixture and those fed only cells of a naturally occurring species of Euglena (Mann-Whitney $U$-test, p > 0.05).

In situ grazing rates ranged from 4.2 to $9.8 \mu \mathrm{g}$ pigment ind. ${ }^{-1} \mathrm{~d}^{-1}$ (mean $5.8 \pm 2.0 \mathrm{SD} \mu \mathrm{g}$ pigment ind. ${ }^{-1}$ 


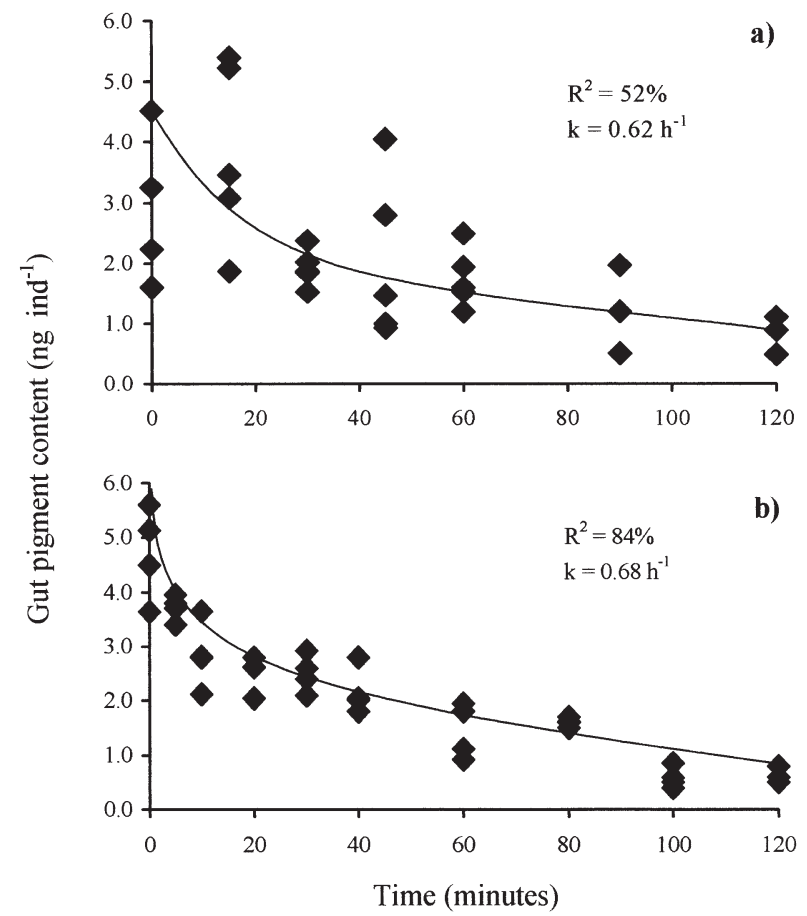

Fig. 4. Gastrosaccus brevifissura. Gut-evacuation rates (k) measured during (a) August 1999, (b) February 2000

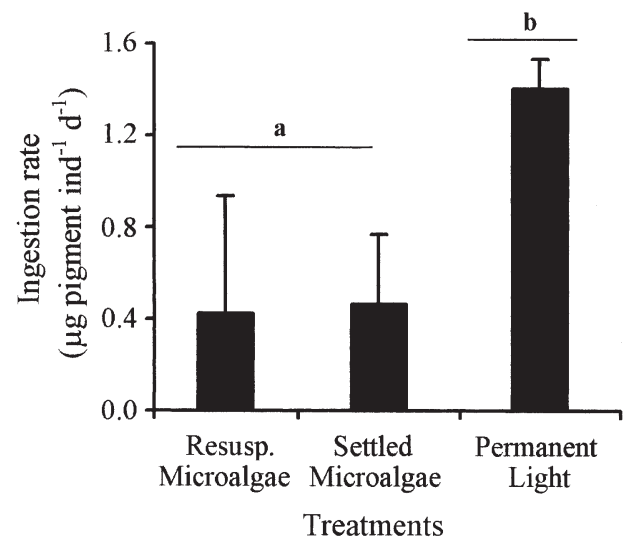

Fig. 5. Gastrosaccus brevifissura. Grazing rates (mean \pm SD) in the 3 treatments of the in vitro grazing experiments conducted in the Mpenjati Estuary, 3 and 4 July 2000. Lines a and $\mathrm{b}$ indicate significant differences between treatments (1-way ANOVA)

$\mathrm{d}^{-1}$ ) during August 1999 and from 0.24 to $0.39 \mu \mathrm{g}$ pigment ind..$^{-1} \mathrm{~d}^{-1}$ (mean $0.29 \pm 0.06 \mathrm{SD} \mu \mathrm{g}$ pigment ind. ${ }^{-1}$ $\mathrm{d}^{-1}$ ) during February 2000. The entire estuarine population of Gastrosaccus brevifissura grazed $1.82 \mathrm{mg}$ pigment $\mathrm{m}^{-2} \mathrm{~d}^{-1}$ and $0.24 \mathrm{mg}$ pigment $\mathrm{m}^{-2} \mathrm{~d}^{-1}$, accounting for a grazing impact of 31.6 and $22 \%$ of the available phytoplankton in the estuary during winter and summer, respectively.
Table 1. Gastrosaccus brevifissura. Results of 1-way ANOVA of feeding treatments for mysid in the Mpenjati Estuary, 3 and 4 July 2000. ${ }^{*}$ Significant at $p<0.05$

\begin{tabular}{|lrccc|}
\hline Source of variation & df & MS & $F$ & $p$ \\
\hline Treatment & 2 & 27.0 & 13.0 & $<0.01^{*}$ \\
Error & 9 & 2.07 & & \\
Total & 11 & & & \\
\hline
\end{tabular}

Table 2. Gastrosaccus brevifissura. Results of Tukey HSD post hoc test of feeding treatments for mysid in the Mpenjati Estuary, 3 and 4 July 2000 . Significant at ${ }^{*} p<0.05 ;{ }^{* *} p<0.01$

\begin{tabular}{|lllc|}
\hline Treatment & $\begin{array}{c}\text { Resuspended } \\
\text { microalgae }\end{array}$ & $\begin{array}{c}\text { Settled } \\
\text { microalgae }\end{array}$ & Permanent \\
& & & \\
\hline $\begin{array}{l}\text { Resuspended microalgae } \\
\text { Settled microalgae }\end{array}$ & 1.00 & & \\
Permanent light & 0.544 & 1.00 & \\
& $0.002^{* *}$ & $0.011^{*}$ & 1.00 \\
\hline
\end{tabular}

On average, in vitro ingestion rates of Gastrosaccus brevifissura were higher in the PL treatment $(1.40 \pm$ $0.13 \mathrm{SD} \mu \mathrm{g}$ pigment ind.$\left.^{-1} \mathrm{~d}^{-1}\right)$ than in the SM $(0.46 \pm$ $0.30 \mathrm{SD} \mu \mathrm{g}$ pigment ind.$\left.^{-1} \mathrm{~d}^{-1}\right)$ and RM $(0.42 \pm 0.51 \mathrm{SD}$ $\mu \mathrm{g}$ pigment ind. ${ }^{-1} \mathrm{~d}^{-1}$ ) treatments (Fig. 5). The PL treatment differed significantly from the RM and the SM treatments (1-way ANOVA, $F=9.98, \mathrm{p}<0.05$ and Tukey HSD post hoc test $[p<0.05]$ ) (Fig. 5, Tables 1 \& 2). Generally, in both RM and SM treatments, maximum ingestion rates were 1 order of magnitude lower than grazing rates obtained with the in situ technique.

The $\delta^{13} \mathrm{C}$ content of Gastrosaccus brevifissura ranged from $-20.8 \%$ in winter (August 1999) to $-19 \%$ in summer (February 2000) (mean $-19.9 \pm 1.0 \mathrm{SD} \%$ ). These values were closest to those obtained for BMA, which ranged from -21.9 to $-18.1 \%$ (mean $-20.1 \pm 1.2 \mathrm{SD} \%$ ). The values show an enrichment of 0.65 and $0.8 \%$ from the food source to the consumer during winter and summer, respectively. There were no significant differences between the $\delta^{13} \mathrm{C}$ content of $G$. brevifissura and BMA in winter or in summer (Mann-Whitney $U$-test $\mathrm{p}>0.05$ ) (Table 3). The $\delta^{15} \mathrm{~N}$ content of G. brevifissura ranged from $8.4 \%$ in winter to $11.6 \%$ in summer (mean $10 \pm 1.6 \mathrm{SD} \%$ ). On the other hand, BMA $\delta^{15} \mathrm{~N}$ values ranged from $0.1 \%$ in winter to $6.3 \%$ in summer (mean $2.8 \pm 2.8 \mathrm{SD} \%$ ). The trophic level of G. brevifissura was estimated on the assumption of a ${ }^{15} \mathrm{~N}$ trophic-enrichment factor of $+3.8 \%$ (Hobson \& Welch 1992), and was closer to 2 (primary consumer) than 3 (secondary consumer) during both winter and summer. The dual-mixing model of Ben-David et al. (1997) applied to these data showed that $G$. brevifis- 
Table 3. Gastrosaccus brevifissura. Comparison of $\delta^{13} \mathrm{C}$ contents (\% \pm SD) (Mann-Whitney U-test) of benthic microalgae (BMA), particulate organic matter (POM) and detritus (DTR), during winter (June 1999) and summer (February 2000). ns: not significant; ${ }^{*}$ : significant at $\mathrm{p}<0.05$. Number of replicates in parentheses

\begin{tabular}{|lccccc|}
\hline & \multicolumn{3}{c}{ Winter } & & \multicolumn{2}{c|}{ Summer } \\
& $\delta^{13} \mathrm{C}$ & $Z$ & $\mathrm{p}$ & $\delta^{13} \mathrm{C}$ & $\mathrm{p}$ \\
\hline G. brevifissura & $-20.80 \pm 0.00(2)$ & & & $-19.05 \pm 0.07(2)$ & \\
BMA & $-21.19 \pm 0.82(3)$ & 0.58 & $0.80 \mathrm{~ns}$ & $-19.53 \pm 0.92(6)$ & 0.67 \\
POM & $-23.08 \pm 0.95(3)$ & 1.91 & $0.06 \mathrm{~ns}$ & $-18.53 \pm 1.53(6)$ & 0.50 \\
DTR & $-26.27 \pm 0.35(3)$ & 1.91 & $0.05^{*}$ & $-23.67 \pm 0.48(6)$ & 2.01 \\
\end{tabular}

Table 4. Mean $( \pm \mathrm{SD}) \delta^{13} \mathrm{C}$ and $\delta^{15} \mathrm{~N}$ content of potential food sources: benthic microalgae (BMA), particulate organic matter (POM), detritus (DTR) and their percentage contribution to the diet of Gastrosaccus brevifissura in the Mpenjati Estuary during winter (June 1999) and summer (February 2000). Number of replicates in parentheses

\begin{tabular}{|lrcc|}
\hline $\begin{array}{l}\text { Food source } \\
\text { Season }\end{array}$ & \multicolumn{1}{c}{$\delta^{13} \mathrm{C}$} & $\delta^{15} \mathrm{~N}$ & $\begin{array}{c}\text { Contribution } \\
(\%)\end{array}$ \\
\hline BMA & & & \\
Winter & $-21.20 \pm 0.82(3)$ & $5.33 \pm 1.19(3)$ & 68 \\
Summer & $-19.53 \pm 0.92(6)$ & $1.50 \pm 2.48(6)$ & 24 \\
POM & & & \\
Winter & $-23.08 \pm 0.95(3)$ & $7.0 \pm 0.44(3)$ & 16 \\
Summer & $-18.53 \pm 1.53(6)$ & $4.63 \pm 0.93(6)$ & 55 \\
DTR & & & \\
Winter & $-26.27 \pm 0.35(3)$ & $4.8 \pm 0.40(3)$ & 16 \\
Summer & $-23.67 \pm 0.48(6)$ & $2.97 \pm 0.74(6)$ & 21 \\
\hline
\end{tabular}

sura received over $68 \%$ of its food requirements from BMA during winter and $24 \%$ during summer; different proportions of POM and DTR were also consumed during the same periods (Table 4).

\section{DISCUSSION}

Virtually the entire population of Gastrosaccus brevifissura in the Mpenjati Estuary was present in the water column during the night. Conversely, it burrowed in the sediment during the daylight period (when it was generally collected by the scraping action of a hand-held D-net). This behaviour is typical for many mysid species, particularly within the genus Gastrosaccus (Mauchline 1980, Wooldridge 1999), and is widely believed to be an adaptive strategy of avoidance of visual predators (Gliwicz 1986, Jerling \& Wooldridge 1992).

In a parallel survey in the lower reaches of the estuary, Kibirige (2002) found that total night-time zooplankton abundances during the winter closed phase ranged from 17 to $3.6 \times 10^{4}$ ind. $\mathrm{m}^{-3}$. During the summer open phase, night-time zooplankton abundance values ranged from 39 to $1.3 \times 10^{3}$ ind. $\mathrm{m}^{-3}$. Thus, during the winter, Gastrosaccus brevifissura constituted $\sim 50 \%$ of the total zooplankton biomass in the lower reaches of the estuary. In summer, however, following the opening of the estuary's mouth, the biomass of the mysid dropped dramatically, representing less than $3 \%$ of the total zooplankton stock. Although the sampling frequency (i.e. every second month) was not ideal for the determination of seasonal patterns, it is quite clear that highest biomass (Fig. 2) and abundance levels of $G$. brevifissura occurred during the winter closed phase. This coincided with the occurrence of peak concentrations in phytoplankton and microphytobenthic biomass in the estuary (Perissinotto et al. 2002).

In situ measurements of grazing rates on autotrophic material showed that Gastrosaccus brevifissura can consume more than $30 \%$ of the phytoplankton biomass available in the water column per day (Kibirige 2002, Kibirge \& Perissinotto 2003). This implies, therefore, that the daily phytoplankton production of the Mpenjati Estuary may at times not be sufficient to support all the energetic requirements of $G$. brevifissura (Perissinotto et al. 2002). Another autotrophic food source potentially available to mysids in the estuary is BMA (Perissinotto et al. 2002). Microphytobenthic biomass in the Mpenjati is particularly high, with re-

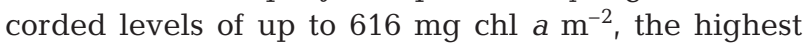
ever recorded in any South African estuary and indeed among the highest reported in the literature. It is also 1 to 2 orders of magnitude higher than vertically integrated phytoplankton biomass (Perissinotto et al. 2002). Since G. brevifissura lives in close association with the sediment, at least during the daytime, it seems reasonable that substantial proportions of the microphytobenthos may indeed be used as an alternative food source.

This is indicated by the results of the stable isotope analysis on the 3 main potential food sources available in the estuary (i.e. BMA, suspended POM and plant DTR). The $\delta^{13} \mathrm{C}$ values for Gastrosaccus brevifissura were closest to those of BMA (Table 3). Furthermore, the dual-mixing model of Ben-David et al. (1997) 
revealed that $68 \%$ of $G$. brevifissura's diet came from BMA during the winter closed phase and $24 \%$ during the summer open phase (Table 4 ). These observations are similar to the results obtained by Stoner \& Zimmerman (1988) and Primavera (1996). These authors concluded that paeneid shrimps obtain the bulk of their carbon from BMA rather than from mangrove DTR.

DTR also comprised 16 and $21 \%$ of the total diet of Gastrosaccus brevifissura during the winter closed phase and the summer open phase, respectively (Table 4). Small detrital particles are difficult to isolate from the other particulate components and may be included as part of the suspended POM. Little DTR material was observed in samples from the Mpenjati Estuary analysed under the dissecting microscope. Stable isotope $\left(\delta^{13} \mathrm{C}\right.$ and $\left.\delta^{15} \mathrm{~N}\right)$ analyses showed a clear separation between POM and DTR, again indicating that the contribution of the latter to the total particulate load was probably minimal at the time of the survey.

Highest gut-pigment contents were observed during the night time, clearly showing that Gastrosaccus brevifissura feeds more during the night-time than during the daytime (Fig. 3). However, the gut-pigment contents during the day were much higher than those of starved individuals (mean $=0.09 \mathrm{ng}$ ind.$^{-1}$ ), suggesting that $G$. brevifissura actively feeds during the day as well. Similarly, Fleeger et al. (1999) reported that the grass shrimp Palaemonetes pugio consumed microalgae associated with marsh edges throughout a $24 \mathrm{~h}$ cycle, exhibiting gut-pigment contents often in excess of 1 to $2 \mu \mathrm{g}$ ind.-1 even in daylight. They also reported that the values attained during the afternoon were significantly higher than those measured during the morning.

In the in vitro experiments, Gastrosaccus brevifissura exhibited significant lower feeding rates in the RM and SM treatments than in the PL treatment (Fig. 5, Tables 1 \& 2). Since under conditions of exposure mysids are forced to remain burrowed in the sediment throughout the daily cycle, our results show that G. brevifissura is able to feed efficiently on settled as well as on resuspended BMA, corroborating the evidence presented above and supporting the hypothesis that, at least in the presence of high concentrations of BMA, G. brevifissura may be able to extract much of its energy demands from this source, apart from water column phytoplankton.

Daily rations for Gastrosaccus brevifissura were estimated using the relationship of carbon content versus dry weight of Beers (1966) and Parsons et al. (1984): $\mathrm{C}=35$ to $43 \% \mathrm{DW}$. The average carbon content of $G$. brevifissura ranged from 0.62 to $1.09 \mathrm{mg} \mathrm{C}$ ind. ${ }^{-1}$ dur-

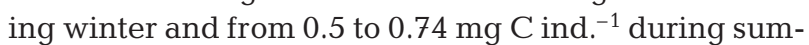
mer. Using the average ingestion rates obtained with the in situ grazing method, these values would corre- spond to carbon rations ranging from 35 to $44 \%$ in winter and from 1.6 to $3.9 \%$ in summer. In a study conducted parallel to this, Marshall et al. (2003) report basal metabolic $\mathrm{O}_{2}$ consumption rates for $G$. brevifissura ranging from 1.22 to $2.95 \mu \mathrm{g} \mathrm{O}_{2}$ ind..$^{-1} \mathrm{~h}^{-1}$ at a temperature of $21^{\circ} \mathrm{C}$ (representative of winter in situ conditions) and from 1.93 to $4.23 \mu \mathrm{g} \mathrm{O}_{2}$ ind. $^{-1} \mathrm{~h}^{-1}$ at $25^{\circ} \mathrm{C}$ (representative of summer in situ conditions in the Mpenjati Estuary).

Conversion of these rates into carbon ingestion equivalents (Perissinotto et al. 2001), reveals a percent body carbon requirement per day of 1.57 to $4.02 \%$ (at $21^{\circ} \mathrm{C}$ ) and 1.43 to $3.67 \%$ (at $25^{\circ} \mathrm{C}$ ).

To enable the mysid to meet all its energetic requirements, rations about 5 to 10 times higher than those for basal metabolic requirements are needed (Atkinson \& Snÿder 1997, Perissinotto et al. 1997, 2001). Thus, our results show that in situ carbon rations obtained in winter are 1 order of magnitude higher than the basal metabolic rate, suggesting that during this season Gastrosaccus brevifissura may be able to meet all its energetic requirements for moulting, reproduction and growth from a microalgal diet only. During summer, however, carbon rations are barely enough to meet the basal metabolic requirements of the mysids, indicating that other food sources are ingested during this period to complement its diet.

Incidentally, the summer open phase of the estuary coincides with a scarcity of phytoplankton as well as microphytobenthic biomass (Perissinotto et al. 2002). It has also been suggested that during this period of microalgae scarcity, the zooplankton grazers of the estuary, including Gastrosaccus brevifissura, may become more opportunistic in their feeding patterns (Kibirige et al. 2002). This is supported by studies of Mauchline (1980) and Siegfried \& Kopache (1980), who show that mysids are generally omnivorous on micro- and mesozooplankton. Pechen'-Finenko \& Pavlovskaya (1975) reported that Neomysis mirabilis fed on a range of diets, including plant and animal detritus, melanin and dinoflagellates. Furthermore, in the Baltic Sea, Mysis mixta and M. relica change their diet according to the availability of food resources and changing seasons (Viitasalo et al. 1995, Uitto et al. 1997, Koski et al. 1999, Viherluoto et al. 2000, Viherluoto \& Viitasalo 2001). This has important implications, because mysids act as key links between lower and higher trophic levels (Aneer 1980, Arrhenius \& Hansson 1993). Globally, there is a scarcity of data on the feeding rates and preferences of estuarine mysids. The few studies carried out in South Africa so far have indicated that mysids are capable of feeding on a variety of heterotrophic materials (Wooldridge \& Bailey 1982, Wooldridge \& Webb 1988, Jerling \& Wooldridge 1995a,b). G. brevifissura plays an important and often 
key role in estuarine food webs (Wooldridge \& Bailey 1982), and its ability to switch to a periodically heterotrophic diet during part of the year may have important implications for the entire trophic structure of this ecosystem.

Acknowledgements. This study was mainly funded through a Joint Venture Project between the National Research Foundation (NRF), Pretoria, and the Department of Environmental Affairs \& Tourism (DEA\&T). The Universities of Natal and Durban-Westville also provided funds and facilities. We wish to thank the Research Section of KwaZulu-Natal Wildlife, and the management and staff of the Mpenjati Reserve for providing logistic support and for allowing the use of facilities during the field surveys. Finally, we are grateful to J.-F. Holley for his invaluable help with field and laboratory work.

\section{LITERATURE CITED}

Aneer G (1980) Estimates of feeding pressure on pelagic and benthic organisms by Baltic herring (Clupea harengus v. membras L.). Ophelia 1:265-275

Arrhenius F, Hansson S (1993) Food consumption of larval, young and adult herring and sprat in the Baltic Sea. Mar Ecol Prog Ser 96:125-137

Atkinson A, Snÿder R (1997) Krill-copepod interactions at South Georgia, Antarctica. I. Omnivory by Euphausia superba. Mar Prog Ecol Ser 160:63-76

Beers JR (1966) Studies on chemical composition of the major zooplankton groups in the Sargasso Sea off Bermuda. Limnol Oceanogr 11:520-528

Ben-David M, Flynn RW, Schell DM (1997) Annual changes in diets of martens: evidence from stable isotope analysis. Oecologia 111:280-291

Bligh EG, Dyer RM (1959) A rapid method of total lipid extraction and purification. Can J Biochem Physiol 37:911-917

Brown AC, Talbot MS (1972) The ecology of the sandy beaches of the Cape Peninsula, South Africa, Part 3: a study of Gastrosaccus psammodytes Tattersall (Crustacea: Mysidacea). Trans R Soc S Afr 40:309-333

Cariou-Le Gall V, Blanchard G (1995) Monthly HPLC measurements of pigment concentration from an intertidal muddy sediment of Marennes-Oléron Bay, France. Mar Ecol Prog Ser 121:171-179

Couch CA (1989) Carbon and nitrogen stable isotopes of meiobenthos and their food resources. Estuar Coast Shelf Sci 28:433-441

De Jonge VN, Colijn F (1994) Dynamics of microphytobenthos biomass in the Ems estuary. Mar Ecol Prog Ser 104: 185-196

Fleeger JW, Carman KR, Webb S, Hilbun N, Pace MC (1999) Consumption of microalgae by the grass shrimp Palaemonetes pugio. J Crustac Biol 19:324-336

Frost BW (1972) Effects of size and concentration of food particles on the feeding behaviour of the marine planktonic copepod Calanus pacificus. Limnol Oceanogr 17:805-815

Gliwicz MZ (1986) Predation and the evolution of vertical migration in zooplankton. Nature 320:746-748

Hedges JI, Parker PL (1976) Land-derived organic matter in surface sediments from the Gulf of Mexico. Geochim Cosmochim Acta 40:1019-1029

Hobson KA, Welch HE (1992) Determination of trophic relationships within a high Arctic marine food web using $\delta^{13} \mathrm{C}$ and $\delta^{15} \mathrm{~N}$ analysis. Mar Ecol Prog Ser 84:9-18
Huntley ME, Boyd CM (1984) Food-limited growth of marine zooplankton. Am Nat 124:455-478

Jerling HL, Wooldridge TH (1992) Lunar influence on distribution of a calanoid copepod in the water column of a shallow, temperate estuary. Mar Biol 112:309-412

Jerling HL, Wooldridge TH (1995a) Feeding of two mysid species on plankton in a temperate South African estuary. J Exp Mar Biol Ecol 188:243-259

Jerling HL, Wooldridge TH (1995b) Plankton distribution and abundance in the Sundays River Estuary, South Africa with comments on potential feeding interactions. S Afr J Mar Sci 15:169-184

Jerling HJ, Wooldridge TH (1995c) Relatively negative $\delta^{13} \mathrm{C}$ ratios of mesozooplankton in the Sundays River Estuary, comments on potential carbon sources. S Afr J Aquat Sci 21(1/2):71-77

Kibirige I (2002) The structure and trophic role of the zooplankton community of the Mpenjati Estuary, a subtropical and temporarily-open system on the KwaZulu-Natal coast. PhD thesis, University of Durban-Westville, South Africa

Kibirige I, Perissinotto R (2003) In situ feeding rates and grazing impact of zooplankton in a South African temporarily open estuary. Mar Biol 142:357-367

Kibirige I, Perissinotto R, Nozais C (2002) Alternative food sources of zooplankton in a temporarily-open estuary: evidence from $\delta^{13} \mathrm{C}$ and $\delta^{15} \mathrm{~N}$. J Plankton Res 24(10):1089-1095

Koski M, Viitasalo M, Kuosa H (1999) Seasonal development of mesozooplankton biomass and production on the SW coast of Finland. Ophelia 50:69-91

Lobban CS, Harrison PJ, Duncan MJ (1985) The physiological ecology of sea weeds. Cambridge University Press, New York

Mackas D, Bohrer R (1976) Fluorescence analysis of zooplankton gut contents and an investigation of diel feeding patterns. J Exp Mar Biol Ecol 25:77-85

Mallin MA, Paerl HW (1994) Planktonic trophic transfer in an estuary: seasonal, diel and community structure effects. Ecology 75(8):2168-2184

Marin V, Huntley ME, Frost B (1986) Measuring feeding rates of pelagic herbivores: analysis of experimental design and methods. Mar Biol 93:49-58

Marshall DJ, Perissinotto R, Holley JF (2003) Respiratory responses of the mysid Gastrosaccus brevifissura (Peracarida: Mysidacea), in relation to body size, temperature and salinity. Comp Biochem Physiol A134:257-266

Mauchline J (1980) The biology of mysids and euphausiids. Adv Mar Biol 18:1-681

Nozais C, Perissinotto R, Mundree S (2001) Annual cycle of microalgal biomass in a South African temporarily-open estuary: nutrient versus light limitation. Mar Ecol Prog Ser 223:39-48

Pakhomov EA, Perissinotto R (1996) Trophodynamics of the hyperiid amphipod Themisto gaudichaudi in the South Georgia region during late austral summer. Mar Ecol Prog Ser 134:91-100

Parsons TR, Takahashi M, Hargrave B (1984) Biological oceanographic processes. Pergamon Press, Oxford

Pechen'-Finenko GA, Pavlovskaya TV (1975) Comparative evaluation of the role of detritus and algae in the nutrition of mysids Neomysis mirabilis (Czerniavsky). Gidrobiol Zh $11: 39-44$

Perissinotto R (1992) Mesozooplankton size-selectivity and grazing impact on the phytoplankton community of the Prince Edward Archipelago (Southern Ocean). Mar Ecol Prog Ser 79:243-258

Perissinotto R, Wooldridge TH (1989) Short-term thermal 
effects of a power-generating plant on zooplankton in the Swartkops Estuary, South Africa. PSZN I: Mar Ecol 10: 205-219

Perissinotto R, Pakhomov EA, McQuaid CD, Froneman PW (1997) In situ grazing rates and daily ration of Antarctic krill Euphausia superba feeding on phytoplankton at the Antarctic Polar Front and the Marginal Ice Zone. Mar Ecol Prog Ser 160:77-91

Perissinotto R, Walker DR, Webb P, Wooldridge TH, Bally R (2000) Relationships between zoo- and phytoplankton in a warm-temperate, semi-permanently closed estuary, South Africa. Estuar Coast Shelf Sci 51:1-11

Perissinotto R, Mayzaud P, Labat JP, Razouls S (2001) Grazing dynamics of Euphausia spinifera in the region of the Subtropical Convergence and the Agulhas Front. Can J Fish Aquat Sci 58:273-281

Perissinotto R, Nozais C, Kibirige I (2002) Spatio-temporal dynamics of phytoplankton and microphytobenthos in a South African temporarily-open estuary. Estuar Coast Shelf Sci 55:47-58

Peters RH (1984) Methods for the study of feeding, grazing and assimilation by zooplankton. In: Downing JA, Rigler $\mathrm{FH}$ (eds) A manual on methods for the assessment of secondary productivity. Blackwell Scientific Publications, Oxford, p 336-412

Primavera JH (1996) Stable carbon and nitrogen isotope ratios of penaeid juveniles and primary producers in a riverine mangrove in Gumaras, Philippines. Bull Mar Sci 58:675-683

Ribes M, Coma R, Gili JM (1998) Seasonal variation of in situ feeding rates by the temperate ascidian Halocynthia papillosa. Mar Ecol Prog Ser 175:201-213

Riera P, Richard P (1996) Isotopic determination of food sources of Crassostrea gigas along a trophic gradient in the Estuarine Bay of Marennes-Oléron. Estuar Coast Shelf Sci 42: $347-360$

Rigler FH (1971) Feeding rates. In: Edmonson WT, Winberg GG (eds) A manual on methods for the assessment of secondary productivity in freshwaters. Blackwell, Oxford: p 228-256 (IBP Handbook No 17)

Round FF (1981) The ecology of algae. Cambridge University Press, Cambridge

Schwinghamer P, Tan FC, Gordon DC (1983) Stable carbon isotope studies of Pecks Cove mudflat ecosystem in the Cumberland Basin, Bay of Fundy. Can J Fish Aquat Sci 40: 262-272

Siegfried CA, Kopache ME (1980) Feeding of Neomysis mercedis (Holmes). Biol Bull 159:193-205

Stoner AW, Zimmerman RJ (1988) Food pathways associated with penaied shrimp in a mangrove-fringed estuary. Fish Bull US 86:543-551

Talbot MMJF, Baird D (1985) Feeding of the estuarine round herring Gilchristella aestuarius ( $\mathrm{G} \& \mathrm{~T}$ ) (Stolephoridae). J Exp Mar Biol Ecol 87:199-214

Editorial responsibility: Otto Kinne (Editor), Oldendorf/Luhe, Germany
Tan FC, Cai DL, Edmond JM (1991) Carbon isotope geochemistry of the Changjiang Estuary. Estuar Coast Shelf Sci 32:395-403

Tattersall OS (1952) Report on a small collection of Mysidacea from estuarine waters of South Africa. Trans R Soc S Afr 33:153-188

Tranter DJ, Fraser JH (1968) Zooplankton sampling. UNESCO, Paris

Uitto A, Heiskanen AS, Lignell R, Autio R, Pajuniemi R (1997) Summer dynamics of the coastal planktonic food web in the northern Baltic Sea. Mar Ecol Prog Ser 151:27-41

Viherluoto M, Viitasalo M (2001) Temporal variability in functional responses and prey selectivity of the pelagic mysid, Mysis mixta, in natural prey assemblages. Mar Biol 138: 575-583

Viherluoto M, Kuosa H, Flinkman J, Viitasalo M (2000) Food utilisation of pelagic mysids, Mysis mixta and M. relicta, during their growing season in the northern Baltic Sea. Mar Biol 136:553-559

Viitasalo M, Vuorinen I, Saesmaa S (1995) Mesozooplankton dynamics in the northern Baltic Sea: implications of variations in hydrography and climate. J Plankton Res 17: $1857-1878$

Webb P, Perissinotto R, Wooldridge TH (1987) Feeding of Mesopodopsis slabberi (Crustacea, Mysidacea) on naturally occurring phytoplankton. Mar Ecol Prog Ser 38: 115-123

Webb P, Wooldridge TH, Schlacher TA (1997) Osmoregulation and spatial distribution of four species of mysid shrimps. Comp Biochem Physiol A 117:427-431

Welschmeyer NA (1994) Fluorometric analysis of chlorophyll-a in the presence of chlorophyll-b and pheopigments. Limnol Oceanogr 39:1985-1992

Whitfield AK (1992) A characterisation of southern African estuarine systems. S Afr J Aquat Sci 18:89-103

Wooldridge TH (1976) The zooplankton of Msikaba Estuary. Zool Afr 11:23-44

Wooldridge TH (1977) The zooplankton of Mgazana, a mangrove estuary in Transkei, Southern Africa. Zool Afr 12: 307-322

Wooldridge TH (1999) Estuarine zooplankton community structure and dynamics. In: Allanson BR, Baird D (eds) Estuaries of South Africa. Cambridge University Press, Cambridge, p 141-166

Wooldridge TH, Bailey C (1982) Euryhaline zooplankton of the Sundays Estuary and notes on trophic relationships. S Afr J Zool 17:151-163

Wooldridge TH, McLachlan A (1987) A new species of Gastrosaccus (Mysidacea) from the south-west coast of Africa. Crustaceana 52(1):101-111

Wooldridge TH, Webb P (1988) Predator-prey interactions between two species of estuarine mysid shrimps. Mar Ecol Prog Ser 50:21-28

Submitted: June 17, 2002; Accepted: December 17, 2002 Proofs received from author(s): March 17, 2003 